\title{
The Isolation and Characterization of Bacteriophages Infecting Obligately Thermophilic Strains of Bacillus
}

\author{
By R. J. SHARP, ${ }^{1 *}$ S. I. AHMAD ${ }^{3}$ A. MUNSTER,${ }^{1}$ B. DOWSETT ${ }^{2}$ \\ AND T. ATKINSON ${ }^{1}$ \\ ${ }^{1}$ Microbial Technology Laboratory and ${ }^{2}$ Experimental Pathology Laboratory, PHLS Centre for \\ Applied Microbiology and Research, Porton Down, Salisbury SP4 OJG, UK \\ ${ }^{3}$ Department of Life Sciences, Trent Polytechnic, Burton Street, Nottingham NG1 4BU, UK
}

(Received 15 October 1985; revised 22 December 1985)

\begin{abstract}
Twenty-four thermophilic bacteriophages have been isolated from diverse sources such as compost, soil, silage and rotting straw. Although considerable individual host specificity was observed, the phages were able to infect most of the major taxonomic groups of Bacillus thermophiles. The phages varied considerably in morphology and size; the phage heads were either cylindrical or polyhedral with tails varying in length between 15 and $500 \mathrm{~nm}$. Most of the phages were stable at $50^{\circ} \mathrm{C}$ for $4-5 \mathrm{~h}$ but at $70^{\circ} \mathrm{C}$ the plaque-forming units decreased by between $10^{2}$ - and $10^{7}$-fold in $2 \mathrm{~h}$. The DNA of morphologically similar phages was examined by restriction enzyme analysis, and some differences in the DNA fragment patterns were found. Efficiency of plating data indicated that ' $B$. caldotenax' has a restriction and modification system. These phages may be valuable for the study of the genetics of thermophilic bacilli: transduction of ' $B$. caldotenax' and 'B. caldovelox' by phage JS017 has been observed.
\end{abstract}

\section{INTRODUCTION}

A few thermophilic bacteriophages able to infect strains of Bacillus stearothermophilus have been isolated and characterized. These include $\phi \mu-4$ (Thompson \& Shafia, 1962), TP1C (Welker \& Campbell, 1965), TP84 (Saunders \& Campbell, 1965), T $\phi 3$ (Egbert \& Mitchell, 1967), D5 (Reanney \& Wood, 1973), and the earlier isolates of White et al. (1955) and Koser (1926). B. stearothermophilus is an extremely heterogeneous group of micro-organisms, with strains described having DNA compositions varying from 42 to $71 \mathrm{~mol} \% \mathrm{G}+\mathrm{C}$ (Sharp \& Woodrow, 1982). Walker \& Wolf (1971) described three major sub-groups of B. stearothermophilus and a number of minor groups based on biochemical and physiological character. 'Bacillus caldotenax', ' $B$. caldovelox' and ' $B$. caldolyticus', isolated from hot springs in Yellowstone National Park (Heinen \& Heinen, 1972), are closely related to the previously described obligately thermophilic sporeformer, 'B. kaustophilus' (Prickett, 1928), now designated $B$. stearothermophilus ATCC 8005 . Their minimum growth temperature is $42^{\circ} \mathrm{C}$ and all grow at $75^{\circ} \mathrm{C}$; their spores are oval and terminal with swelling of the sporangia.

The aim of this research was to isolate phages able to infect the major taxonomic groups of $B$. stearothermophilus and to provide a relatively simple means of sub-group identification.

\section{METHODS}

Organisms. 'B. caldotenax' DSM 406, 'B. caldovelox' DSM 411, 'B. caldolyticus' DSM 405, the Bacillus thermophile RS 93, and B. stearothermophilus strains NCA 1503, NW 10, EP 240, EP 262, EP 136, DSM 2334 and ATCC 12016 were used as phage-sensitive indicator strains. These strains have been described by Sharp et al. (1980) and Wolf \& Sharp (1981).

Streptomycin-resistant $\left(\mathrm{Str}^{\mathrm{r}}\right)$ strains of B. stearothermophilus NCA 1503 and the Bacillus thermophiles RS 239, RS 240, RS 241 and RS 242 were selected following repeated subculture on Tryptone Soya Agar (TSA, Oxoid CM31) supplemented with streptomycin at 15-100 $\mathrm{g} \mathrm{ml}^{-1}$ (Sharp \& Woodrow, 1982). 
Additional strains used in examining phage host range were $B$. stearothermophilus NW 4S (Welker \& Campbell, 1965), B. coagulans A TCC 8038 and ATCC 12245, B. stearothermophilus A TCC 8005, Bacillus thermophile strains RS 15, RS 108, RS 125 (Sharp \& Woodrow, 1982), 'B. thermocatenulatus' DSM 730, B. subtilis 168 and $B$. amyloliquefaciens $\phi 1$.

Phages. TP1C and TP84 were from Dr N. E. Welker, North West University, Illinois, USA. Phage ATCC 12016B was obtained from the American Type Culture Collection. $\phi 29$ was from Dr B. Reilly, University of Minnesota, USA. $\phi 1$ was from Dr J. Spizizen, University of Arizona, Tucson, Arizona, USA. Phage JS001 was obtained by induction of $B$. stearothermophilus NCA 1503.

Media. Bacteria were routinely maintained and subcultured on TSA, which was also used as the basal medium for phage plating. Trypticase agar (Welker \& Campbell, 1965) was used to overlay the phage and bacteria assay mixture.

Cultures were grown in Tryptone Soya Broth (TSB, Oxoid CM131) and BS medium (Sargeant et al., 1971).

Phage maintenance and assay. Phages were maintained as suspensions in culture supernatant or PMN buffer $\left(0.01 \mathrm{M}-\mathrm{KH}_{2} \mathrm{PO}_{4}, 0.05 \mathrm{M}-\mathrm{NaCl}, 0.001 \mathrm{M}-\mathrm{MgCl}_{2}, \mathrm{pH} 7.0\right.$ with $\left.\mathrm{KOH}\right)$. Sterility was maintained by the addition of chloroform to the suspension. This was ineffective against spores from certain strains, e.g. RS 93, and some phages were chloroform sensitive. Alternatively phage suspensions were sterilized by filtration through a $0.45 \mu \mathrm{m}$ Millex disposable filter unit (Millipore).

Phages were titrated by the soft-agar double-layer technique (Adams, 1959) using $0.6 \%(\mathrm{w} / \mathrm{v})$ trypticase soft agar supplemented with $0.015 \mathrm{M}-\mathrm{CaCl}_{2}$. Phage dilutions were made in $0.09 \%(\mathrm{w} / \mathrm{v})$ saline or PMN buffer and were incubated at $55^{\circ} \mathrm{C}$ unless stated otherwise.

Isolation of phages from soil and compost samples using a range of indicator strains. Samples ( $5 \mathrm{~g})$ of soil, mud, compost, etc., were added to $100 \mathrm{ml} \mathrm{TSB}$ and incubated at $55^{\circ} \mathrm{C}$ for $7 \mathrm{~h}$. After removal of the cells and debris by centrifugation, $10 \mathrm{ml}$ samples were inoculated with a range of potential phage-sensitive indicator strains. Dilutions of filtered culture supernatant were plated with the respective potential host strains, using soft agars. Single plaques were transferred with tooth picks to $5 \mathrm{ml} \mathrm{PMN} \mathrm{buffer} \mathrm{for} \mathrm{replating.} \mathrm{Three} \mathrm{successive} \mathrm{reselection}$ steps were made for each plaque type isolated.

Isolation of phages for specific strains (after Romig \& Brodetsky, 1961). Samples (5 g) of soil, mud or compost were added to $15 \mathrm{ml}$ water and incubated at $50^{\circ} \mathrm{C}$ for $24 \mathrm{~h}$. The samples were shaken and then allowed to stand for $30 \mathrm{~min}$ to allow debris to settle. A sample $(5 \mathrm{ml})$ from the top layer was added to $10 \mathrm{ml}$ TSB (supplemented with $0.015 \mathrm{M}-\mathrm{CaCl}_{2}$ ) and incubated at $55^{\circ} \mathrm{C}$. After $4 \mathrm{~h}, 10 \mathrm{ml}$ fresh TSB, $1.5 \mathrm{ml}$ of a $6-8 \mathrm{~h}$ culture of a Str ${ }^{\mathrm{r}} \mathrm{strain}$ of $B$. stearothermophilus and $50 \mu \mathrm{g}$ streptomycin $\mathrm{ml}^{-1}$ were added. Incubation was continued for a further $6 \mathrm{~h}$. After centrifugation at $4000 \mathrm{~g}$ for $20 \mathrm{~min}$ the culture supernatant was diluted and plated on the appropriate $\operatorname{Str}^{\mathrm{r}} \mathrm{strain}$. Single plaques were isolated and purified as described above.

Production of phage lysates. Phage suspensions of up to $10^{9}$ p.f.u. $\mathrm{ml}^{-1}$ were prepared after lysis in the soft agar layer of double-layered plates.

The host strain was incubated in $10 \mathrm{ml} \mathrm{BS}$ broth at $55^{\circ} \mathrm{C}$ for $5-6 \mathrm{~h}$, giving a cell density of $5 \times 10^{7}-10^{8}$ viable cells $\mathrm{ml}^{-1}$. Cell suspension $(0.5 \mathrm{ml})$ and phage suspension $\left(0.5 \mathrm{ml} ; 10^{5}-10^{6}\right.$ p.f.u. $\left.\mathrm{ml}^{-1}\right)$ were added to $3 \mathrm{ml}$ trypticase soft agar at $55^{\circ} \mathrm{C}$, spread over TSA plates and incubated overnight at $55^{\circ} \mathrm{C}$. The soft agar layer was removed using a $10 \mu \mathrm{l}$ disposable loop to a $50 \mathrm{ml}$ centrifuge tube, mixed with $10 \mathrm{ml}$ PMN buffer (approximately $5 \mathrm{ml}$ additional buffer was added for each extra plate used) and centrifuged at $6000 \mathrm{~g}$ for $15 \mathrm{~min}$. For transduction studies, or stock suspensions, the supernatant was generally sterilized by filtration and not purified further.

To obtain sufficient phage for DNA isolation, infections were carried out in liquid medium. The host strain was grown in TYF broth (Welker \& Campbell, 1965) in $500 \mathrm{ml}$ or $1000 \mathrm{ml}$ Erlenmeyer flasks at $55^{\circ} \mathrm{C}$, shaken at 150 r.p.m. At mid-exponential phase $\left(\mathrm{OD}_{420} 0.55-0.6\right)$ the phage suspension was added (to give a multiplicity of infection of 0.1$)$ together with $\mathrm{CaCl}_{2}(0.015 \mathrm{M})$ and glucose $(0.4 \%, \mathrm{w} / \mathrm{v})$. Incubation was continued for a further 3-4 h before collecting the culture supernatant. Phage titres were in the region of $10^{10}-10^{11}$ p.f.u. $\mathrm{ml}^{-1}$.

When phage preparations were to be used for electron microscopy, or for DNA isolation or buoyant density studies, they were concentrated and further purified. The lysate supernatant was treated with DNAase, RNAase and lysozyme (each $10 \mu \mathrm{g} \mathrm{ml}^{-1}$ ) plus $203 \mu \mathrm{g} \mathrm{MgCl}, 6 \mathrm{H}_{2} \mathrm{O} \mathrm{ml} \mathrm{m}^{-1}$, and incubated for $2 \mathrm{~h}$ at $37^{\circ} \mathrm{C}$. The phage were then sedimented by centrifugation at $30000 \mathrm{~g}$ for $3 \mathrm{~h}$. The pellet was resuspended in 2-5 $\mathrm{ml}$ PMN buffer and dialysed against $2 \times 2$ litres PMN buffer for $48 \mathrm{~h}$. The phage particles were centrifuged for $24 \mathrm{~h}$ on a $5 \mathrm{ml} \mathrm{CsCl}$ gradient $(7.5 \mathrm{M}-\mathrm{CsCl}$ in $0.02 \mathrm{M}$-Tris buffer $\mathrm{pH} 7.2)$ at $160000 \mathrm{~g}$ at $6^{\circ} \mathrm{C}$. Phage bands were collected and dialysed for 24 h against $2 \times 2$ litres PMN buffer.

Study of phage plaque morphology and host range. Plaque morphology was examined after plating phage dilutions with the appropriate indicator strain and incubating at $60^{\circ} \mathrm{C}$ for $16-18 \mathrm{~h}$.

Phage suspensions $\left(10^{6}\right.$ p.f.u. $\left.\mathrm{ml}^{-1}\right)$ were prepared after infection of the most suitable host available (generally 'B. caldotenax', B. stearothermophilus NCA 1503, or strains RS 239 to RS 242). The preparation was serially diluted and dilutions were plated against a range of test strains.

Examination of host restriction and modification of phages. Phages were harvested following lysis on two independent host strains. The two phage populations were then titrated on both host strains. The phage titre on the 
original host strain was considered to represent an e.o.p. of 1 and was compared with the e.o.p. on the second host strain.

Thermal inactitation of phages. Suspensions of bacteriophage in $\mathrm{PMN}$ buffer were adjusted to $10^{-}-$ $10^{8}$ p.f.u. $\mathrm{ml}^{-1}: 3 \mathrm{ml}$ volumes were placed in $5 \mathrm{ml}$ Pyrex tubes in $50^{\circ} \mathrm{C}, 60^{\circ} \mathrm{C}$ and $70^{\circ} \mathrm{C}$ water baths, and $0.5 \mathrm{ml}$ samples were titrated on the appropriate host at intervals up to $4.5 \mathrm{~h}$.

Determination of buoyant density of phage particles. Percoll (Pharmacia) $(49.5 \mathrm{ml})$ was mixed with $1.5 \mathrm{M}-\mathrm{NaCl}$ $(5.5 \mathrm{ml})$ to prepare an iso-osmotic stock solution. This solution was mixed with an equal volume of $0 \cdot 1 \mathrm{M}-\mathrm{NaCl}$ and $7 \mathrm{ml}$ added to ultracentrifuge tubes $(7 \mathrm{ml})$. Concentrated phage preparations $(100 \mu \mathrm{l})$ were loaded on the top of Percoll gradients. Two control tubes, used to prepare a calibration curve for each centrifuge run, were prepared with $10 \mu \mathrm{l}$ each of nine density marker beads (Pharmacia) ranging from 1.017 to $1.143 \mathrm{~g} \mathrm{ml}^{-1}$. After centrifugation at $60000 \mathrm{~g}$ for $15 \mathrm{~min}$ the distance from the base of the tube of the phage bands in the Percoll gradients was measured and buoyant densities were determined by reference to the calibration curve.

Examination of phages by electron microscopy. Phage suspensions were purified on $\mathrm{CsCl}$ gradients followed by dialysis for $48 \mathrm{~h}$ against $2 \times 1$ litre PMN buffer. A drop of the purified suspension $\left(10^{10} \mathrm{p} . \mathrm{f}\right.$.u. $\left.\mathrm{ml}^{-1}\right)$ was placed on a 200 mesh copper specimen grid coated with a Formvar/carbon film. After approximately $30 \mathrm{~s}$ the drop was gently removed by touching the edge of the grid with a piece of filter paper. A drop of negative stain $(1 \%, w / v$, phosphotungstic acid, $\mathrm{pH}$ 6.8) was then placed on the grid and similarly removed after approximately $10 \mathrm{~s}$. The grids were examined in either a Philips EM300 or a Philips EM400T electron microscope operated at an accelerating voltage of $80 \mathrm{kV}$. Micrographs were recorded on Ilford EM technical film at magnifications of $\times 28000-\times 46000$. Negatives were developed in Kodak D163 developer and printed on Ilford print photographic paper, enlarging $\times 2$ or $\times 3$.

DNA isolation and purification. After overnight dialysis against 1000 vols PMN buffer, phage preparations were adjusted to a minimum of $10^{11}$ p.f.u. $\mathrm{ml}^{-1}$. Proteinase K (BDH) dissolved in PMN buffer was added $\left(20 \mu \mathrm{g} \mathrm{ml} \mathrm{m}^{-1}\right)$ and the mixture was incubated at $37^{\circ} \mathrm{C}$ for $30 \mathrm{~min}$. The phages were then dialysed for $6 \mathrm{~h}$ at $4{ }^{\circ} \mathrm{C}$ against 500 vols PMN buffer. The dialysis buffer was then changed to formamide buffer $(200 \mathrm{mM}-\mathrm{Tris} / \mathrm{HCl}, \mathrm{pH} 7.5 ; 10 \mathrm{mM}-$ $\mathrm{Na}_{2}$ EDTA; $50 \%$ formamide; $\mathrm{pH}$ to 8.5 with $4 \mathrm{M}-\mathrm{HCl}$ ) for $16 \mathrm{~h}$, followed by $48 \mathrm{~h}$ dialysis against $2 \times 1000$ vols $20 \mathrm{~mm}$-Tris, $1 \mathrm{mM}$-EDTA buffer, $\mathrm{pH} 7 \cdot 5$. Phage DNA was assayed by absorbance at $260 \mathrm{~nm}$ and its purity assessed by the absorbance ratio at $260: 280: 230 \mathrm{~nm}$.

A phenol extraction method derived from that of Saunders \& Campbell (1965) was also used. An equal volume of $90 \%(\mathrm{v} / \mathrm{v})$ phenol equilibrated twice against PMN buffer was added to the phage suspension in saline EDTA $(0.15 \mathrm{M}-\mathrm{NaCl}, 0.1 \mathrm{M}$-EDTA, $\mathrm{pH} 8.0)$ and shaken for $30 \mathrm{~min}$ at $4{ }^{\circ} \mathrm{C}$. The aqueous phase was extracted three times with diethyl ether and the DNA was precipitated with 2 vols cold $95 \%(\mathrm{v} / \mathrm{v})$ ethanol. The DNA was dissolved in $0.1 \times$ SSC buffer (Marmur \& Doty, 1962) and dialysed for $48 \mathrm{~h}$ at $4^{\circ} \mathrm{C}$ against $2 \times 1000$ vols $20 \mathrm{~mm}$-Tris, $1 \mathrm{~mm}$ EDTA buffer, pH 7.5.

The DNA was purified further by $\mathrm{CsCl}$ /ethidium bromide density centrifugation. A total of $5 \mathrm{ml}$ DNA suspension in $20 \mathrm{~mm}$-Tris, $1 \mathrm{~mm}$-EDTA ( $\mathrm{pH} \mathrm{7.5)}$ was added to $5 \mathrm{~g} \mathrm{CsCl}$ with $50 \mu$ l ethidium bromide solution $\left(10 \mathrm{mg} \mathrm{ml}^{-1}\right)$. The mixture was transferred to $10 \mathrm{ml}$ polycarbonate centrifuge tubes and centrifuged at $150000 \mathrm{~g}$ at $6{ }^{\circ} \mathrm{C}$ for $20 \mathrm{~h}$. The DNA bands were visualized under UV light and were collected with a $2 \mathrm{ml}$ syringe. Ethidium bromide was removed by washing twice with an equal volume of isoamyl alcohol. The DNA was then dialysed for $24 \mathrm{~h}$ against 2000 vols PMN buffer.

Examination of phage DNA with restriction endonucleases. DNA samples were dialysed overnight against a lowsalt buffer (10 mM-Tris, $10 \mathrm{~mm}-\mathrm{MgSO}_{4}, 1 \mathrm{~mm}$-dithiothreitol, $\left.\mathrm{pH} 7 \cdot 4\right)$. DNA (1 $\mu \mathrm{g}$ ) was incubated in $20 \mu \mathrm{l}$ of this buffer with 1-2 units of enzyme for $3 \mathrm{~h}$ at $37^{\circ} \mathrm{C}$ (or $60^{\circ} \mathrm{C}$ when using endonuclease $B c / \mathrm{I}$ ). The digested samples were heated at $70^{\circ} \mathrm{C}$ for $5 \mathrm{~min}$ to inactivate the enzyme. Electrophoresis was done in a Protean double-slab electrophoresis cell (Bio-Rad). Vertical slab gels with 15 wells $(3 \mathrm{~mm}$ wide) were prepared using $0.8 \%$ (w/v) agarose dissolved in Tris/borate buffer ( $90 \mathrm{mM}$-Tris; $90 \mathrm{~mm}$-boric acid; $3 \mathrm{~mm}-\mathrm{Na}_{2}$ EDTA; pH 8.0). An equal volume of loading buffer $(0.02 \%$, w/v, bromophenol blue; $20 \%, \mathrm{w} / \mathrm{v}$, sucrose; $0.5 \%$, w/v, Ficoll; 10 mM-EDTA; $5 \mathrm{~mm}-\mathrm{Tris} / \mathrm{HCl} ; \mathrm{pH} \mathrm{7.5)}$ was added to each sample. Gels were electrophoresed in Tris/borate buffer ( $\mathrm{pH} 8)$ for $3 \mathrm{~h}$ at $30 \mathrm{~mA}$, stained in ethidium bromide $\left(2 \mu \mathrm{g} \mathrm{m}^{-1}\right)$ for $0.5 \mathrm{~h}$ and destained for $16 \mathrm{~h}$ before examination on a UV transilluminator $(254 \mathrm{~nm})$. They were photographed using a Polaroid MP-4 land camera with an orange Wratten gelatin filter (Kodak).

\section{RESULTS}

\section{Phage isolation and maintenance}

Ten samples of organic material, including compost, soil and rotting vegetation, were examined for thermophilic phages using ten indicator strains. Many of the phage plaques evident in the initial isolation were lost on transfer to fresh media: all phages isolated on $B$. stearothermophilus strains NCA 1503 and EP 240 were lost, together with a number able to infect strain RS 93, 'B. caldotenax' and 'B. caldovelox'. 
Thirteen phages, JS004-JS015 and JS027, were isolated by the method of Romig \& Brodetsky (1961). Seven source materials were examined (compost, silage, rotting straw, river sludge, stable manure, soil and digested sewage sludge) for the presence of phage using five $\operatorname{Str}^{\mathrm{r}}$ strains (B. stearothermophilus NCA 1503 and the Bacillus thermophiles RS 239, RS 240, RS 241 and RS 242). No phages were isolated from samples of river sludge or digested sewage sludge. One plaque type was isolated from stable manure, one from soil, three from silage, four from rotting straw and six from compost.

A number of thermophilic phage isolates were lost when chloroform was used to sterilize the preparations. Studies on the long-term survival of JS017 in PMN buffer with chloroform indicated a tenfold reduction in viability over $10-20 \mathrm{~d}$ with little further reduction over the next $200 \mathrm{~d}$. The control sample showed a slight (two- to threefold) decrease in viability over $250 \mathrm{~d}$. Suspensions of JS017 in filtered culture supernatant without chloroform showed no loss in p.f.u. after one year at $4{ }^{\circ} \mathrm{C}$. Sterilization with chloroform was unsuccessful in killing spores, particularly in preparations harvested from B. stearothermophilus RS 93.

\section{Plaque morphology of the thermophilic phages}

Table 1 details the plaque morphologies of the thermophilic bacteriophages when plated in trypticase soft agar supplemented with $0.015 \mathrm{M}-\mathrm{CaCl}_{2}$ and incubated overnight at $55^{\circ} \mathrm{C}$. Considerable variations in plaque morphology were observed using identical conditions for plating and incubation. The plaques of phage JS004, following its initial isolation and purification by single-plaque transfer, varied from 0.5 to $2 \mathrm{~mm}$ in diameter, appearing either hazy or clear, and round or irregular. After approximately 12 consecutive single-plaque transfers the morphology stabilized to that described in Table 1. Similar initial variations in plaque morphology were observed with JS006, JS007 and to a lesser extent the other phages isolated using strains RS 239 to RS 242 .

\section{Host restriction and modification of the thermophilic phages}

The host ranges of the phages are shown in Table 2. Evidence was collected during host range studies and titrating of phage preparations which indicated that restriction and modification occurs in thermophilic species of Bacillus (Table 3).

Examination of the e.o.p. of phage JS001 on 'B. caldotenax' and B. stearothermophilus ATCC 12016 (Table 3) indicates restriction by ' $B$. caldotenax' of phage harvested from ATCC 12016. The latter strain, however, did not appear to restrict (e.o.p. 0.75) phage JS001 previously harvested from ' $B$. caldotenax'. Phage JS001 harvested from ' $B$. caldotenax' appeared to be modified, permitting a high level of infection when plated back to ' $B$. caldotenax'. Plating of phage JS001 from ' $B$. caldotenax' with ' $B$. caldovelox' gave an e.o.p. of $0 \cdot 8$, indicating that the latter did not restrict phage from ' $B$. caldotenax' (if dilution and plating variations are taken into account). An e.o.p. of 0.8 was not considered significantly different from an e.o.p. of 1 . The data for phage JS001 harvested from ' $B$. caldotenax' and plated on strains RS 15, RS 93, RS 108, RS 125 and EP 262 illustrate the variation in e.o.p. These data alone, while suggesting restriction, may indicate some inherent resistance in the population to phage infection.

Phages JS019, JS024 and JS025 indicated no evidence of restriction of phages harvested from ' $B$. caldotenax' when plated on ' $B$. caldovelox'. Conversely, these phages harvested from ' $B$. caldovelox' when plated with ' $B$. caldotenax' were restricted, with e.o.p. values of $0 \cdot 28,0 \cdot 12$ and $0 \cdot 125$, respectively. Phages harvested from ' $B$. caldotenax' had a low e.o.p. on ' $B$. caldolyticus'.

Plating of phage JS017 from ' $B$. caldotenax' to ' $B$. caldovelox' again showed no evidence of restriction, but plating on ' $B$. caldolyticus', 'B. thermocatenulatus' and $B$. stearothermophilus ATCC 8005 all indicated the presence of a restriction system. Phage JS017 harvested from ' $B$. caldovelox' also appeared restricted by ' $B$. thermocatenulatus' and ATCC 8005. Phage JS017 isolated from ' $B$. thermocatenulatus' was restricted by ATCC 8005 but unusually gave an e.o.p. of 20 when plated on ' $B$. caldotenax'. 


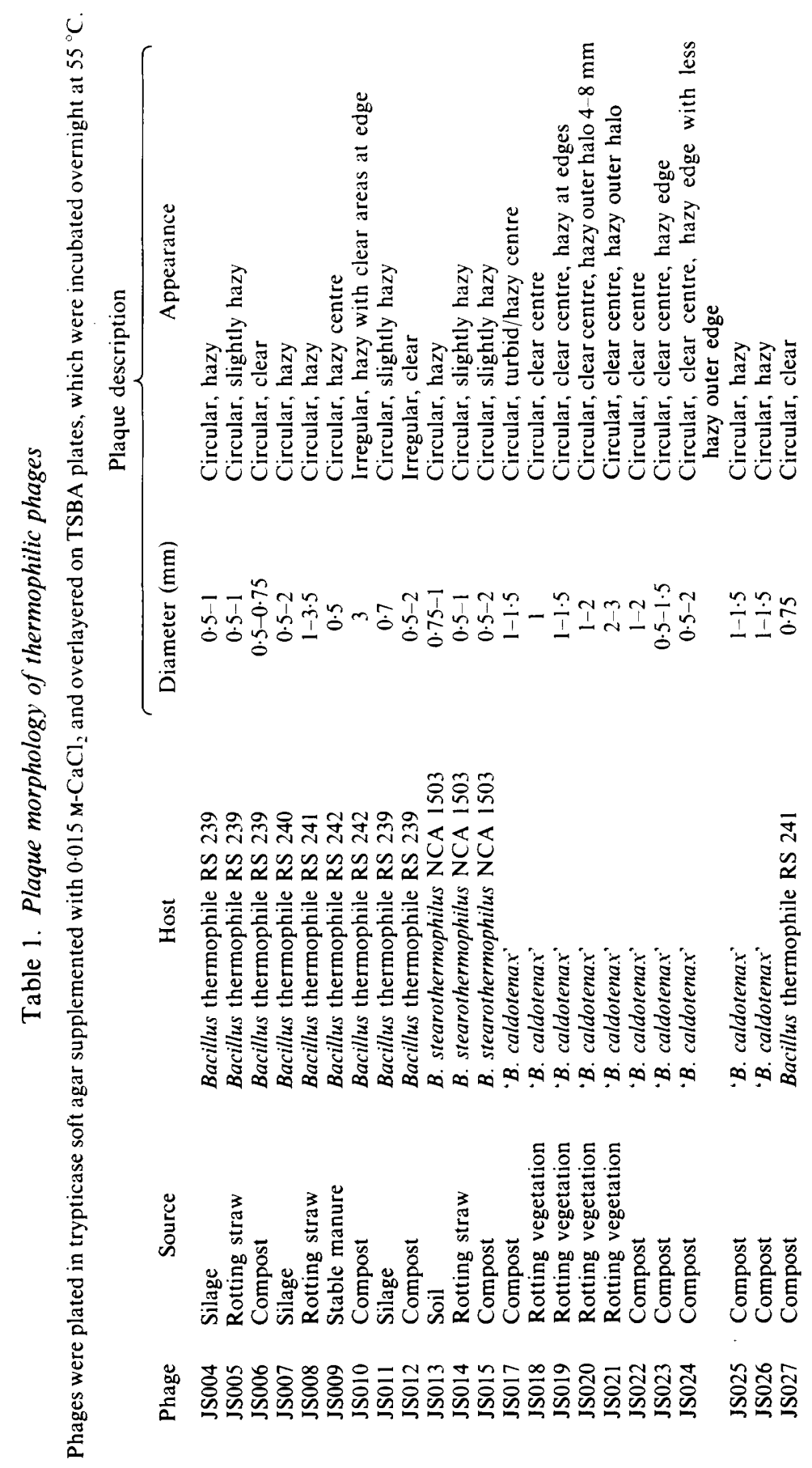


Table 2. Host range of thermophilic phages

Phage suspensions ( $10^{6}$ p.f.u. $\left.\mathrm{ml}^{-1}\right)$ were prepared from lysates of ' $B$. caldotenax' or the most suitable phage host available. Dilutions were then plated with the test strains and observed for plaque formation following overnight incubation at $55^{\circ} \mathrm{C}$. Results were recorded as: $4+$, e.o.p. $1 ; 3+$, e.o.p. $0 \cdot 1-0 \cdot 01$; $2+$, e.o.p. $0.01-0.001 ;+$, e.o.p. $<0.001 ;-$, no evidence of phage infection; $*$, not tested. No phages examined formed plaques on B. coagulans ATCC 8038 and ATCC 12245, B. subtilis 168 and $B$. amyloliquefaciens $\phi 1$. ATCC, American Type Culture Collection; DSM, Deutsche Sammlung von Mikroorganismen; NW, Neil Welker; for EP and RS designated strains see Sharp (1982).

$\begin{array}{ccccccccccccc}\text { Phage ... } & \text { JS } & \text { JS } & \text { JS } & \text { JS } & \text { JS } & \text { JS } & \text { JS } & \text { JS } & \text { JS } & \text { JS } & \text { JS } & \text { JS } \\ \text { Host strain } & 004 & 005 & 006 & 007 & 008 & 009 & 010 & 011 & 012 & 013 & 014 & 015\end{array}$

'B. caldotenax' DSM 406

B. caldovelox' DSM 411

'B. caldolyticus' DSM 405

B. stearothermophilus NCA 1503

B. stearothermophilus ATCC 12016

B. stearothermophilus NW 10

B. stearothermophilus NW 4S

B. stearothermophilus EP 136

B. stearothermophilus RS 93

B. stearothermophilus EP 262

B. stearothermophilus EP 240

B. stearothermophilus ATCC 8005

'B. thermocatenulatus' DSM 730

Bacillus thermophile RS 239

Bacillus thermophile RS 240

Bacillus thermophile RS 241

Bacillus thermophile RS 242

$\begin{array}{cccccccccccc}- & - & - & - & - & - & - & - & - & - & - & - \\ - & - & - & - & - & - & - & - & - & - & - & - \\ - & - & - & - & - & - & - & - & - & - & - & - \\ - & - & - & - & - & - & - & - & - & 3+ & 3+ & 3+ \\ * & * & * & * & - & * & * & * & * & - & - & - \\ - & - & + & - & - & - & - & * & * & 2+ & 2+ & 2+ \\ * & * & * & * & * & * & * & * & * & - & - & - \\ - & - & * & * & - & * & * & * & * & - & - & - \\ 3+ & - & 3+ & 4+ & - & 4+ & + & * & * & + & - & - \\ - & - & + & * & - & * & * & * & * & * & * & * \\ - & - & * & * & - & * & * & * & * & * & * & * \\ * & * & * & * & * & * & * & * & * & * & * & * \\ * & * & * & * & * & * & * & * & * & * & * & * \\ 4+ & 4+ & - & 4+ & 4+ & * & - & * & * & * & * & * \\ - & - & - & 2+ & - & * & - & * & * & * & * & * \\ 2+ & 2+ & - & 4+ & 4+ & 4+ & + & * & * & * & * & * \\ + & - & 2+ & + & - & 2+ & 4+ & * & * & * & * & *\end{array}$

Thermal stability of the thermophilic phages

The temperature sensitivity of phages JS005, JS007, JS014, JS017, JS019, JS024 and JS025, held for $4-5 \mathrm{~h}$ at 50,60 and $70^{\circ} \mathrm{C}$, was examined. After $1 \mathrm{~h}$ at $70^{\circ} \mathrm{C}$ all the phages showed a considerable reduction in p.f.u., which then declined only slightly with continued incubation. At $60^{\circ} \mathrm{C}$ a smaller but significant decrease in p.f.u. was observed within $1-2 \mathrm{~h}$, followed by a levelling off of the p.f.u. Phage JS014 differed from the other phages in that it showed similar rates of inactivation at $60^{\circ} \mathrm{C}$ and $50{ }^{\circ} \mathrm{C}$. At $50^{\circ} \mathrm{C}$ most of the phages showed little decrease in p.f.u. (less than tenfold) after $4 \mathrm{~h}$. Exceptions were JS024 (99\% decrease) and JS025 (99.9\% decrease).

\section{Estimation of buoyant density of the thermophilic phages}

Bouyant density estimations using calibrated Percoll gradients indicated that several of the phages formed two or more bands in the gradients (Table 4). The bands were collected with a syringe and examined for the presence of viable phages. The bouyant density values in Table 4 correspond to either single phage bands or several bands with a high p.f.u. content. The bands with a low p.f.u. content were considered to contain phage debris or ghosts. Although none of these bands were examined by electron microscopy, electron micrographs of phage preparations have shown the presence of many phage ghosts and large numbers of free tails.

\section{Size and morphology of the thermophilic phages}

Electron micrographs (Fig. 1) of 10 of the thermophilic phages show four distinct morphological types (Table 5). Phages JS004 and JS027 were characterized by a comparatively short stubby tail and no evidence of a tail plate. Phages JS019, JS022, JS024 and JS025 all had icosahedral heads of approximately 40-65 nm diameter with tails between $120 \mathrm{~nm}$ and $135 \mathrm{~nm}$ long, and all showed evidence of a tail plate. Phage JS014 had an icosahedral head $85-90 \mathrm{~nm}$ in diameter and a long $(400 \mathrm{~nm})$ flexible tail with helical symmetry. Phages JS017 and JS026 had cylindrical heads with rounded ends, with tails varying between $115 \mathrm{~nm}$ and $120 \mathrm{~nm}$ long. 
Table 2. (continued)

$\begin{array}{cccccccccccc}\text { Phage } \ldots & \text { JS } & \text { JS } & \text { JS } & \text { JS } & \text { JS } & \text { JS } & \text { JS } & \text { JS } & \text { JS } & \text { JS } & \text { JS } \\ \text { Host strain } & 017 & 018 & 019 & 020 & 021 & 022 & 023 & 024 & 025 & 026 & 027\end{array}$

\begin{tabular}{|c|c|c|c|c|c|c|c|c|c|c|c|}
\hline 'B. caldotenax' DSM 406 & $4+$ & $4+$ & $4+$ & $4+$ & $4+$ & $4+$ & $4+$ & $4+$ & $4+$ & $4+$ & - \\
\hline 'B. caldovelox' DSM 411 & $4+$ & $4+$ & $4+$ & $4+$ & $4+$ & $4+$ & $4+$ & $4+$ & $4+$ & $4+$ & - \\
\hline 'B. caldolyticus' DSM 405 & + & $4+$ & + & $4+$ & $3+$ & + & - & $3+$ & $3+$ & $3+$ & - \\
\hline B. stearothermophilus NCA 1503 & - & - & - & - & - & - & - & - & - & - & - \\
\hline B. stearothermophilus ATCC 12016 & $3+$ & - & - & - & + & - & - & - & - & $2+$ & - \\
\hline B. stearothermophilus NW 10 & $2+$ & - & - & - & - & - & - & -- & - & - & - \\
\hline B. stearothermophilus NW 4S & $*$ & * & * & * & * & * & * & $*$ & * & $*$ & - \\
\hline B. stearothermophilus RS 93 & $3+$ & $3+$ & $3+$ & $3+$ & $3+$ & $4+$ & $3+$ & $3+$ & $3+$ & $3+$ & - \\
\hline B. stearothermophilus EP 262 & $2+$ & - & - & - & - & - & - & - & - & - & - \\
\hline B. stearothermophilus EP 240 & + & + & + & + & + & + & - & + & + & - & - \\
\hline B. stearothermophilus ATCC 8005 & $2+$ & $*$ & $*$ & * & - & - & - & - & - & - & - \\
\hline 'B. thermocatenulatus' DSM 730 & $2+$ & $*$ & * & * & - & - & - & - & - & - & - \\
\hline
\end{tabular}

Table 3. Restriction and modification of phages by thermophilic hosts based on the e.o.p.

Phages were titrated using the soft agar plating technique; plates were incubated overnight at $60^{\circ} \mathrm{C}$.

\begin{tabular}{|c|c|c|c|c|}
\hline Phage & $\begin{array}{l}\text { Host used for } \\
\text { preparation of phage }\end{array}$ & $\begin{array}{l}\text { Hosts used for } \\
\text { titration of phage }\end{array}$ & Plaque count & E.o.p. \\
\hline JS001 & 'B. caldotenax' & $\begin{array}{l}\text { 'B. caldotenax' } \\
\text { B. stearothermophilus ATCC } 12016\end{array}$ & $\begin{array}{l}8 \times 10^{8} \\
6 \times 10^{8}\end{array}$ & $\begin{array}{l}1 \\
0.75\end{array}$ \\
\hline JS001 & $\begin{array}{l}\text { B. stearothermophilus } \\
\text { ATCC } 12016\end{array}$ & $\begin{array}{l}\text { B. stearothermophilus ATCC } 12016 \\
\text { 'B. caldotenax' }\end{array}$ & $\begin{array}{l}1 \times 10^{6} \\
1 \times 10^{2}\end{array}$ & $\begin{array}{l}1 \\
0.0001\end{array}$ \\
\hline JS001 & 'B. caldotenax' & $\begin{array}{l}\text { 'B. caldotenax' } \\
\text { 'B. caldovelox' } \\
\text { Bacillus thermophile RS } 15 \\
\text { Bacillus thermophile RS } 108 \\
\text { Bacillus thermophile RS } 125 \\
\text { B. stearothermophilus RS } 93 \\
\text { B. stearothermophilus EP } 262\end{array}$ & $\begin{aligned} & 2.7 \times 10^{5} \\
& 2.2 \times 10^{5} \\
& 5.0 \times 10^{4} \\
& 1.25 \times 10^{4} \\
& 4.0 \times 10^{3} \\
& 1.3 \times 10^{2} \\
& 1.0 \times 10^{1}\end{aligned}$ & $\begin{array}{l}1 \\
0 \cdot 8 \\
0 \cdot 19 \\
0 \cdot 046 \\
0 \cdot 015 \\
0 \cdot 0005 \\
0 \cdot 00004\end{array}$ \\
\hline JS019 & 'B. caldotenax' & $\begin{array}{l}\text { 'B. caldotenax' } \\
\text { 'B. caldovelox' }\end{array}$ & $\begin{array}{l}2 \times 10^{4} \\
2 \times 10^{4}\end{array}$ & 1 \\
\hline JS019 & 'B. caldovelox' & $\begin{array}{l}\text { 'B. caldovelox' } \\
\text { 'B. caldotenax' }\end{array}$ & $\begin{array}{r}1 \times 10^{6} \\
2.8 \times 10^{5}\end{array}$ & $\begin{array}{l}1 \\
0 \cdot 28\end{array}$ \\
\hline JS017 & 'B. caldotenax' & $\begin{array}{l}\text { 'B. caldotenax' } \\
\text { 'B. caldovelox' } \\
\text { 'B. caldolyticus' } \\
\text { 'B. thermocatenulatus' } \\
\text { B. stearothermophilus ATCC } 8005\end{array}$ & $\begin{array}{r}5 \times 10^{7} \\
5 \times 10^{7} \\
1.2 \times 10^{2} \\
1.4 \times 10^{5} \\
1.5 \times 10^{5}\end{array}$ & $\begin{array}{l}1 \\
1 \\
0.000002 \\
0.003 \\
0.003\end{array}$ \\
\hline JS017 & 'B. caldovelox' & $\begin{array}{l}\text { 'B. caldovelox' } \\
\text { 'B. thermocatenulatus' } \\
\text { B. stearothermophilus ATCC } 8005\end{array}$ & $\begin{array}{l}3.2 \times 10^{5} \\
4.0 \times 10^{2} \\
7.0 \times 10^{2}\end{array}$ & $\begin{array}{l}1 \\
0 \cdot 001 \\
0 \cdot 002\end{array}$ \\
\hline JS017 & 'B. thermocatenulatus' & $\begin{array}{l}\text { 'B. thermocatenulatus' } \\
\text { 'B. caldotenax' } \\
\text { B. stearothermophilus }\end{array}$ & $\begin{array}{l}3.0 \times 10^{4} \\
6.0 \times 10^{5} \\
2.0 \times 10^{3}\end{array}$ & $\begin{array}{c}1 \\
20 \\
0 \cdot 07\end{array}$ \\
\hline JS024 & 'B. caldotenax' & $\begin{array}{l}\text { 'B. caldotenax' } \\
\text { 'B. caldovelox' } \\
\text { 'B. caldolvticus' }\end{array}$ & $\begin{array}{l}1 \times 10^{7} \\
7 \times 10^{6} \\
1 \times 10^{5}\end{array}$ & $\begin{array}{l}1 \\
0 \cdot 7 \\
0 \cdot 01\end{array}$ \\
\hline JS024 & 'B. caldovelox' & $\begin{array}{l}\text { 'B. caldovelox' } \\
\text { 'B. caldotenax' }\end{array}$ & $\begin{array}{l}1.2 \times 10^{7} \\
1.4 \times 10^{6}\end{array}$ & $\begin{array}{l}1 \\
0 \cdot 12\end{array}$ \\
\hline JS025 & 'B. caldotenax' & $\begin{array}{l}\text { 'B. caldotenax' } \\
\text { 'B. caldovelox' } \\
\text { 'B. caldolyticus' }\end{array}$ & $\begin{array}{l}1 \times 10^{7} \\
1 \times 10^{7} \\
4 \times 10^{5}\end{array}$ & $\begin{array}{l}1 \\
1 \\
0 \cdot 04\end{array}$ \\
\hline JS025 & 'B. caldovelox' & $\begin{array}{l}\text { 'B. caldotelox' } \\
\text { 'B. caldotenax' }\end{array}$ & $\begin{array}{l}8 \times 10^{6} \\
1 \times 10^{6}\end{array}$ & $\begin{array}{l}1 \\
0 \cdot 125\end{array}$ \\
\hline
\end{tabular}


R. J. SHARP AND OTHERS
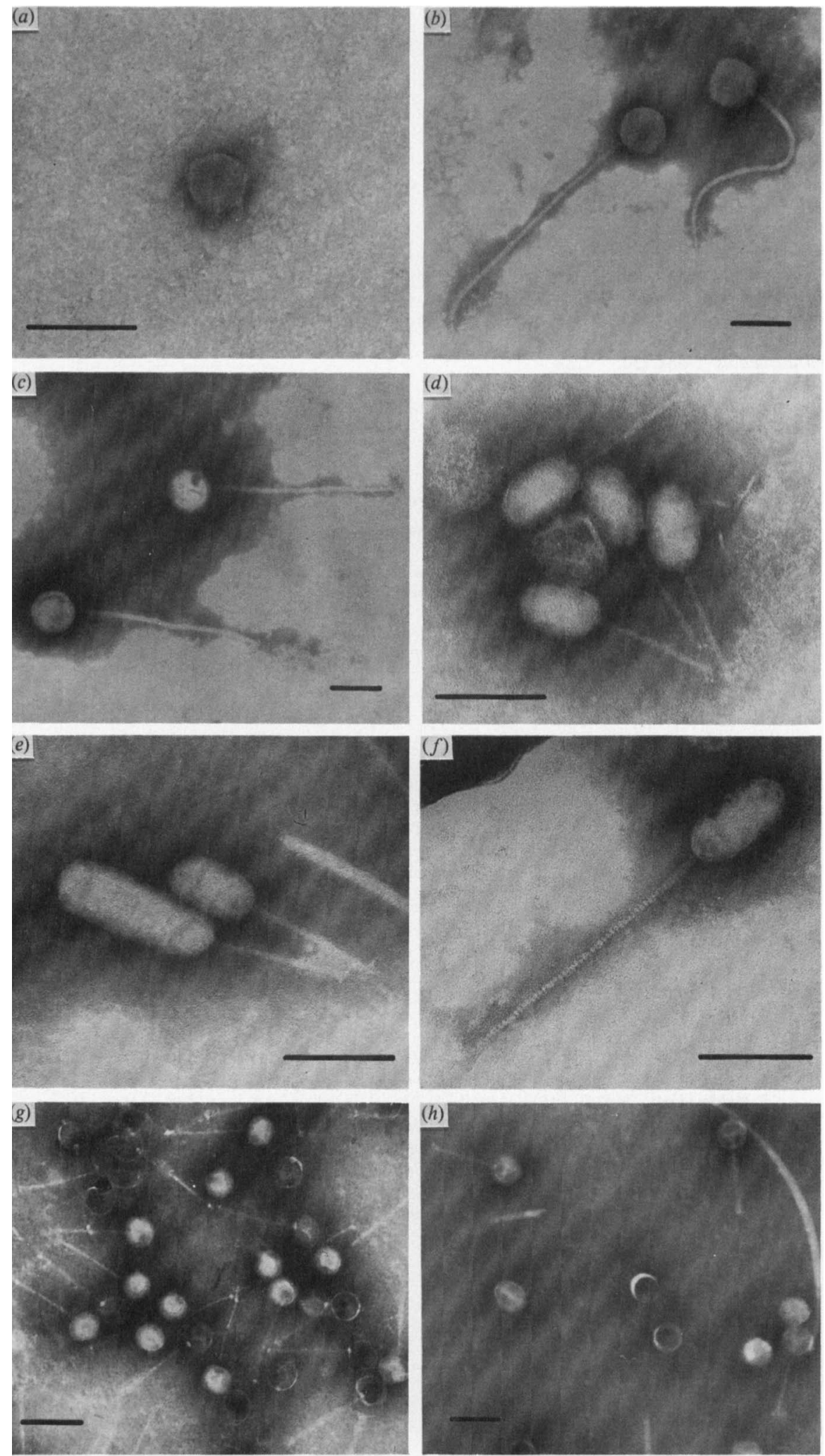

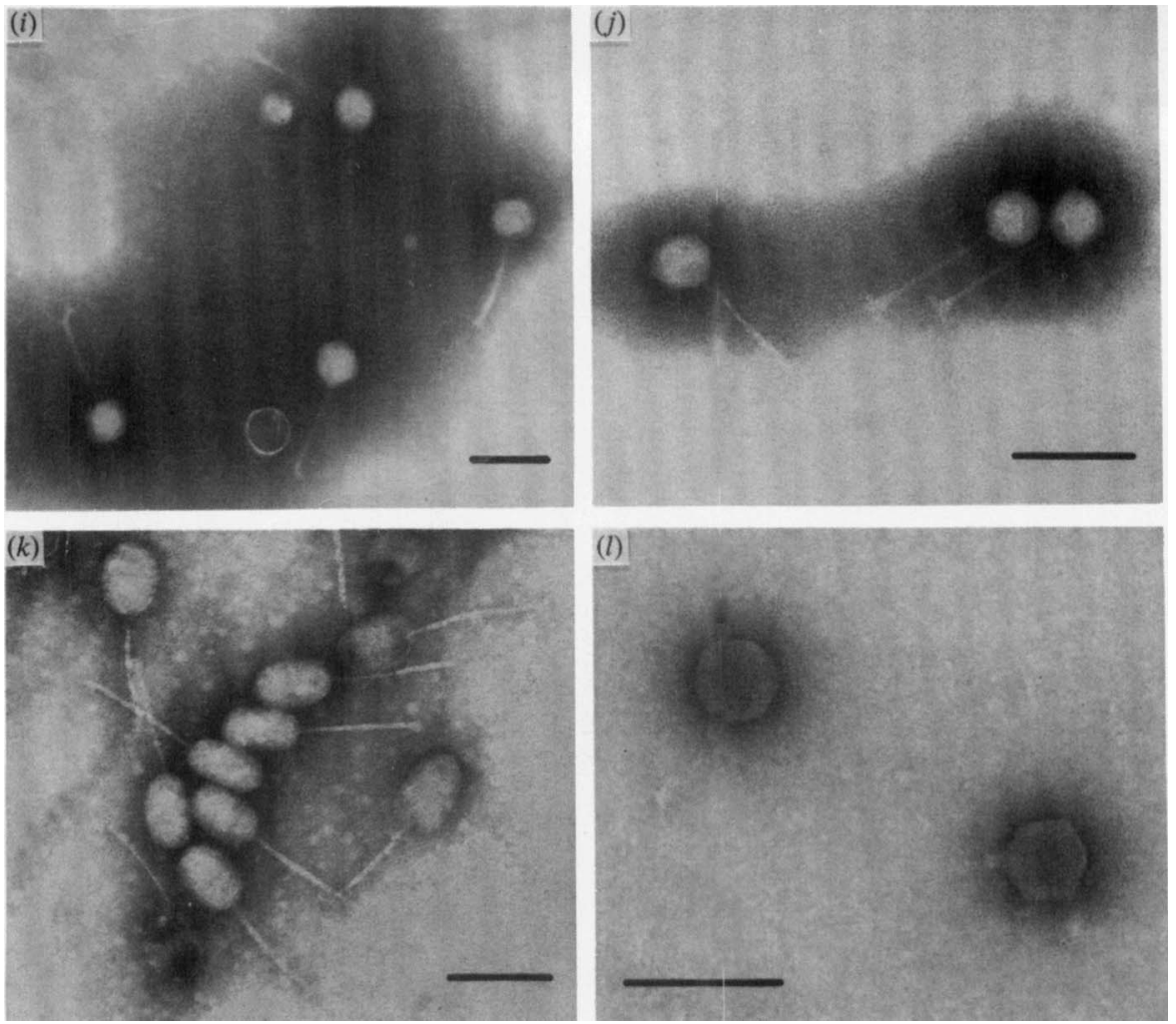

Fig. 1. Electron micrographs of thermophilic phages. (a) JS004, (b) JS007, (c) JS014, (d) JS017, (e) JS017 showing variation in length of the phage heads, $(f)$ JS017 with an unusually long tail, $(g)$ JS019, (h) JS022, (i) JS024, (j) JS025, (k) JS026, (l) JS027. Bars, $100 \mathrm{~nm}$.

Table 4. Determination of buoyant density of phages using calibrated Percoll gradients

Percoll gradients were calibrated with density marker beads. When more than one band was apparent in the gradient, each band was examined for the presence of high numbers of viable phage particles. When the band was wide or consisted of several closely spaced bands with a high p.f.u. content the buoyant density range was recorded.

\begin{tabular}{clc} 
Phage & \multicolumn{1}{c}{$\begin{array}{c}\text { Buoyant density } \\
\text { of high-p.f.u. band }\end{array}$} & $\begin{array}{c}\text { Buoyant density } \\
\text { of low-p.f.u. band } \\
\text { where present }\end{array}$ \\
$\lambda$ & $1.04-1.055$ & - \\
T7 & $1.025-1.05$ & - \\
TP1C & $1 \cdot 1$ & $1.035-1.045$ \\
TP84 & 1.075 & - \\
JS002 & 1.08 & 1.05 \\
JS005 & 1.04 & - \\
JS017 & $1.0,1.02,1.025,1.035$ & - \\
JS019 & 1.045 & - \\
JS022 & 1.065 & 1.04 \\
JS025 & 1.02 & 1.045
\end{tabular}




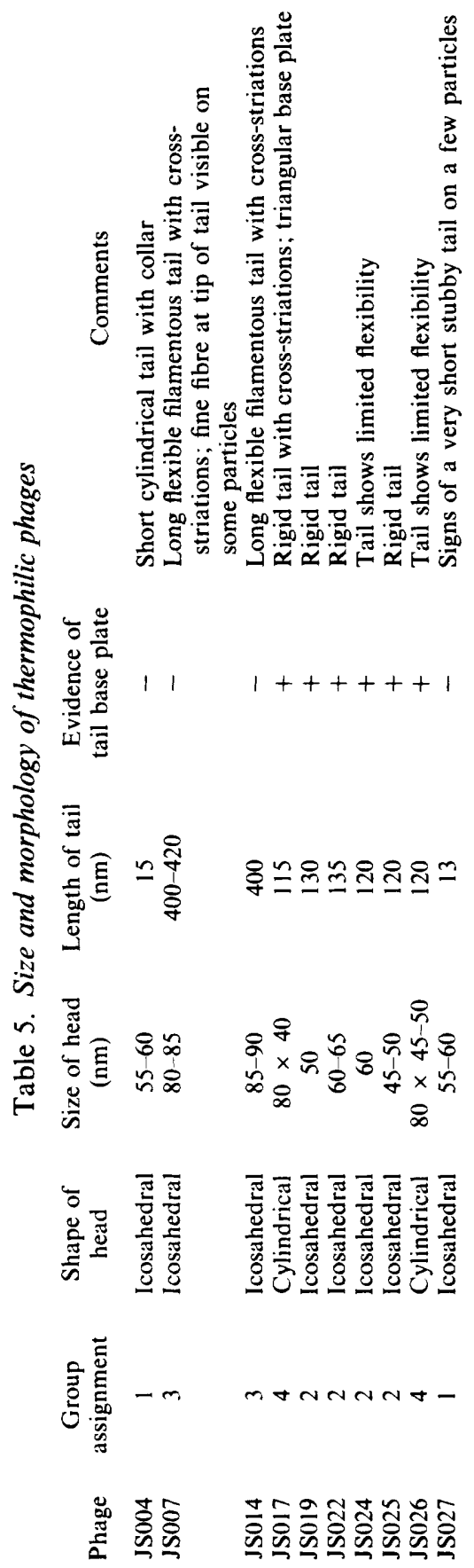




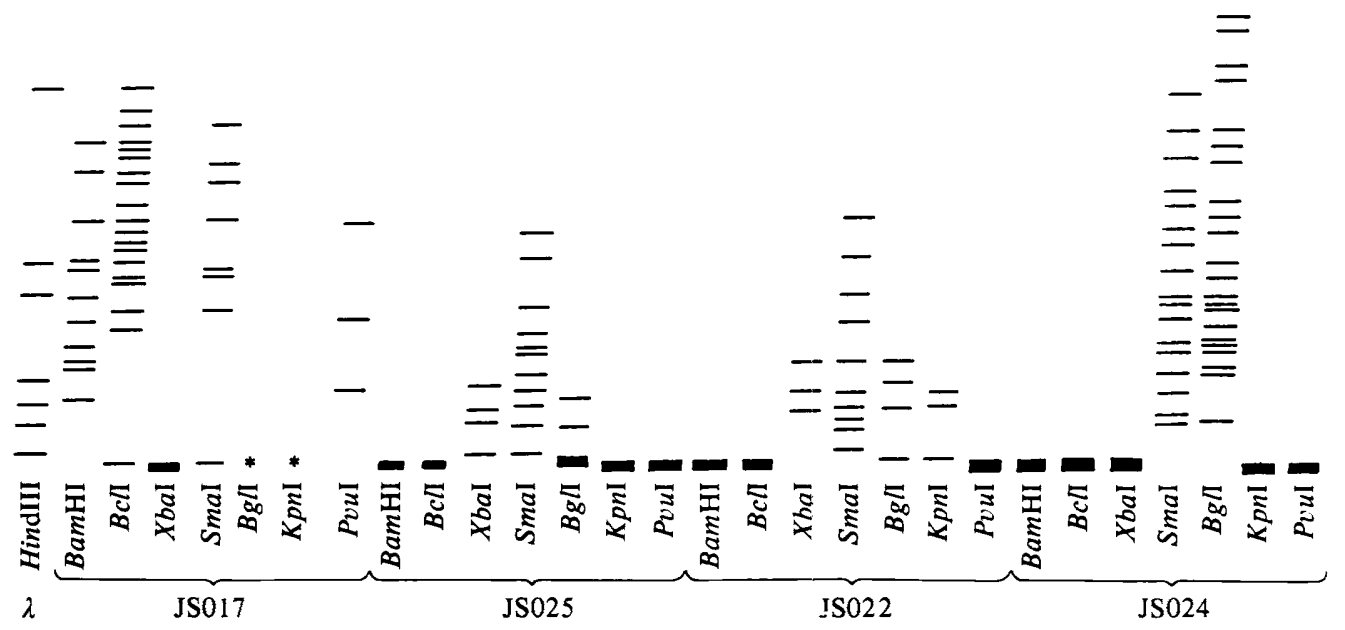

Fig. 2. Diagrammatic representation of restriction endonuclease cleavage fragment patterns of the DNA of four thermophilic phages. All endonuclease digestions were done at $37^{\circ} \mathrm{C}\left(\mathrm{BclI}\right.$ at $\left.60^{\circ} \mathrm{C}\right)$ for $3 \mathrm{~h}$. Enzymes were inactivated at $70^{\circ} \mathrm{C}$ for $5 \mathrm{~min}$ and the samples were loaded onto a $0.8 \%$ agarose gel and run at $30 \mathrm{~mA}$ for $3 \mathrm{~h}$. A HindIII digest of $\lambda$ DNA was included as a size calibration marker. The asterisks indicate smearing of the gel, showing general digestion of the DNA.

Between $1 \%$ and $5 \%$ of the JS017 population had heads of twice the normal length (Fig. $1 e$ ). The occurrence of phage JS017 with longer tails was also observed (Fig. $1 f$ ); the phage head was slightly narrower than the normal head and the tail showed clear evidence of striations or segmentation. Phage ghosts of JS026 and JS017 showed evidence of being waisted at the centre and some of the larger phage heads of JS017 appeared to have striations around the head. Both phages appeared to have a triangular tail plate.

\section{Examination of phage DNA with restriction endonucleases}

DNA from four thermophilic phages was examined after digestion with restriction endonucleases and agarose gel electrophoresis (Fig. 2). This technique enabled the differentiation of phages which appeared morphologically identical. Phage JS017, which was morphologically distinct from the other three phages, had a distinctive restriction endonuclease cleavage pattern. Ten Bam HI sites and $18 \mathrm{BclI}$ sites were evident, whereas none of the remaining three phages showed evidence of DNA cleavage with these enzymes (Fig. 2). A number of enzymes appeared to cause general digestion of the phage JS017 DNA, resulting in smearing of the gel. Phages JS022, JS024 and JS025, which were all morphologically similar, showed several differences in their endonuclease cleavage patterns. JS024 had a minimum of $22 \mathrm{Bg} / \mathrm{I}$ sites compared with four and three for JS022 and JS025, respectively. JS024 also had no XbaI site compared with three and four for JS022 and JS025 respectively. The differences between phages JS022 and JS025 were small and mainly involved slight differences in the number of restriction fragments produced by the different enzymes.

\section{DISCUSSION}

Thermophilic phages infecting a wide range of thermophilic strains of Bacillus were readily isolated from soil and compost. The host range data indicate considerable host specificity. Four distinct taxonomic groups of obligately thermophilic strains of Bacillus, with five subgroups, were described by Sharp \& Woodrow (1982). The phages isolated in this study are specific to three of these taxonomic groups. Phages JS004 to JS012 and JS027 all infect members of subgroup $1 \mathrm{a}$, which are typified by their inability to hydrolyse starch. Those phages were specific to this group and did not infect strains in other taxonomic groups. Phages JS013 to JS015 showed close host specificity to B. stearothermophilus strains NCA 1503 and NW 10, 
which are both members of taxonomic group $2 \mathrm{~b}$. This group represents the classical characteristics of $B$. stearothermophilus and contains the type strain. Phages JS017 to JS026 all infected ' $B$. caldotenax', ' $B$. caldovelox', ' $B$. caldolyticus' and $B$. stearothermophilus ATCC 8005 , all members of taxonomic group $2 \mathrm{a}$. None of the phages infected the two strains of $B$. coagulans examined, or $B$. subtilis and $B$. amyloliquefaciens.

The host range of a phage is influenced by the presence of restriction and modification systems in the host cells. Catterall et al. (1976) speculated that restriction and modification systems in thermophilic bacilli were the rule rather than the exception. Our evidence suggests that ' $B$. caldotenax' has a restriction system which is able to reduce by up to $10^{-4}$ the e.o.p. of phages harvested from some strains of $B$. stearothermophilus. Restriction of phages harvested from ' $B$. caldovelox', which is taxonomically very similar to ' $B$. caldotenax', is evident but at a much lower level. A number of other strains appear to restrict phage infection, including ' $B$. caldolyticus' and Bacillus thermophiles RS 15, RS 93, RS 108 and RS 125.

Four morphological phage types were observed; the majority (JS019, JS022, JS024 and JS025 from lysates of ' $B$. caldotenax') had polyhedral heads $(45-65 \mathrm{~nm}$ in diameter) with tails (120$135 \mathrm{~nm}$ long). Their morphology closely resembles that of the $B$. stearothermophilus phages previously reported: TP1C from lysates of strain 4S (Welker \& Campbell, 1965), TP84 infecting strain NW 10 (Bassel et al., 1971), $\phi \mu-4$ infecting strain NU 10 (Rabussay et al., 1970) and T $\phi 3$ from lysates of ATCC 8005 (Egbert, 1969). Two phages, JS004 and JS027, were distinct in having icosahedral heads, $55-60 \mathrm{~nm}$ in diameter, but short stubby tails, $13-15 \mathrm{~nm}$ long. Phage JS014, which infected B. stearothermophilus NCA 1503, had an icosahedral head $90 \mathrm{~nm}$ in diameter, with a long $(400 \mathrm{~nm})$ flexible tail, showing helical symmetry. Reanney \& Wood (1973) described a phage (D5) isolated from compost, which infected $B$. stearothermophilus NRS T91, a strain derived from the original NCA 1503 isolate (Gordon et al., 1973). Phage D5 was reported to have an icosahedral head $87 \mathrm{~nm}$ in diameter and a striated tail, $180 \mathrm{~nm}$ long (Reanney \& Wood, 1973). Phage JS007, which infected starch-negative strains, had a head of similar diameter $(80-85 \mathrm{~nm})$ and a flexible tail up to $420 \mathrm{~nm}$ long. This appears to be exceptional; Hemphill \& Whitely (1975) reviewed the morphology of $16 \mathrm{~B}$. subtilis phages having tails of between only $30 \mathrm{~nm}$ and $250 \mathrm{~nm}$ in length. The cylindrical heads of phages JS017 and JS026 were morphologically distinct from all previously described thermophilic phages. JS017 showed variable morphology, with some phage heads double the normal length of $80-90 \mathrm{~nm}$. In some preparations these variants numbered between 1 and $5 \%$ of the population and it was initially considered that they might be transducing particles (Munster et al., 1982). Subsequent examination of a number of transducing phage preparations by electron microscopy indicated that whereas the proportion of these variants ranged from 0 to $5 \%$, the transducing ability of the individual preparations did not vary significantly.

$B$. subtilis phages have been characterized or 'fingerprinted' by examination of the restriction endonuclease digestion pattern of their DNA; $\phi 3 \mathrm{~T}, \mathrm{SP} 02$ and $\phi 105$ were examined by Wilson $e t$ al. (1974), and $\phi 29$ and $\phi 15$ by Ito \& Kawamura (1976). Phages JS022, JS024 and JS025 were morphologically identical (Table 5) and all had similar host ranges. Examination of their restriction endonuclease 'fingerprints' (Fig. 2) indicated a close similarity between JS022 and JS025, with small, but significant differences between these two and JS024. Such 'fingerprinting' of thermophilic phages has not been previously reported, but it does offer a relatively simple means of distinguishing between phages with identical host range and morphology.

The buoyant densities of the thermophilic phages in Percoll gradients ranged from 1.0 to $1 \cdot 1 \mathrm{~g} \mathrm{ml}^{-1}$. The occurrence of multiple, or two or three separate bands from individual phage preparations indicated the occurrence of multiple density classes of phage particles. These were probably the result of damaged phage particles which banded separately in the gradient as phage heads and tails. In the examination of several phage preparations by electron microscopy phage ghosts were often predominant; the absence of DNA within the phage heads would result in phage particles with different densities. Karamata (1970) identified multiple density classes of phage $\mathrm{Pl}$ which were the result of tetramer formation through binding at phage base plates. In this form the phages were not infective, although they were protected from inactivation by phage antiserum. The multiple-density bands found in some preparations of thermophilic 
phages were not examined by electron microscopy, although only one such band showed evidence of a high p.f.u. content. The four bands of similar density found for JS017 may be the result of variations in the size of the phage heads and tails as previously observed. A reexamination of the buoyant density of phage JS017 in a Percoll gradient showed two bands, with densities of 0.98 and $1.017 \mathrm{~g} \mathrm{ml}^{-1}$.

Thermal stability studies on seven phage isolates showed few significant differences between them. The p.f.u. of most phage preparations fell less than tenfold after $4-5 \mathrm{~h}$ at $50^{\circ} \mathrm{C}$; the exceptions were JS007, JS024 and JS025, whose p.f.u. decreased by factors of $10^{2}, 10^{2}$ and $10^{3}$, respectively. After $4 \mathrm{~h}$ at $70^{\circ} \mathrm{C}$ the p.f.u. had decreased by between $10^{2}-$ and $10^{7}$-fold. These results were comparable with those reported for most other thermophilic phages. Phage D5 showed little reduction in p.f.u. after $3 \mathrm{~h}$ at $60^{\circ} \mathrm{C}$ but there was a $10^{3}$-fold reduction at $70^{\circ} \mathrm{C}$ (Reanney \& Wood, 1973). Welker \& Campbell (1965) reported a $52 \%$ decrease in p.f.u. of phage TP1C in TYF medium after $30 \mathrm{~min}$ at $65^{\circ} \mathrm{C}$, followed by a levelling out of the survival curve. Phage $\phi \mu-4$ suspended in distilled water showed little decrease in p.f.u. after $1 \mathrm{~h}$ at $75^{\circ} \mathrm{C}$, but there was a $10^{2}$-fold reduction in p.f.u. when the phage were suspended in Tris buffer (Shafia \& Thompson, 1964). Onodera (1961) reported the isolation of an unusual bacteriophage from compost; this infected a thermophilic Bacillus sp. and consisted of spherical particles only $20 \mathrm{~nm}$ in diameter which were resistant to heating at $100^{\circ} \mathrm{C}$ for $2 \mathrm{~h}$.

Bacteriophage JS017 has been reported to carry out specialized transduction of thymine and methionine auxotrophs of ' $B$. caldotenax' (Munster et al., 1982). Other phages are being examined for their ability to carry out generalized transduction, which may be used in support of transformation data in establishing a preliminary genetic map of ' $B$. caldotenax'.

\section{REFERENCES}

ADAMS, M. H. (1959). Bacteriophages. London: Interscience.

Bassel, A., Shaw, M. \& Campbell, L. L. (1971). Dissociation by chelating agents and substructure of the thermophilic bacteriophage TP-84. Journal of Virology 7, 663-672.

Catterall, J. F., Lees, N. D. \& Welker, N. E. (1976). Restriction and modification in thermophilic bacilli. In Microbiology - 1976, pp. 358-366. Edited by $\mathrm{D}$. Schlessinger. Washington, DC: American Society for Microbiology.

EGBERT, L. N. (1969). Characteristics of the DNA of $\mathrm{T} \phi 3$, a bacteriophage for Bacillus stearothermophilus. Journal of Virology 3, 528-532.

EgBert, L. N. \& Mitchell, H. K. (1967). Characteristics of $\mathrm{T} \phi 3$, a bacteriophage for Bacillus stearothermophilus. Journal of Virology 1, 610-616.

Gordon, R. E., Haynes, W. C. \& Pang, C. H.-N. (1973). The Genus Bacillus. Washington, DC: United States Department of Agriculture.

Heinen, U. J. \& Heinen, W. (1972). Characteristics and properties of a caldoactive bacterium producing extracellular enzymes and two related strains. Archiv für Mikrobiologie 82, 1-23.

HEMPHILl, H. E.\& WHITELEY, H. R. (1975), Bacteriophages of Bacillus subtilis. Bacteriological Reviews 39, 257-315.

Ito, J. \& Kawamura, F. (1976). Use of restriction endonucleases in analysing the genomes of bacteriophages $\phi 29$ and $\phi 15$. In Microbiology - 1976, pp. 367-379. Edited by D. Schlessinger. Washington, DC: American Society for Microbiology.

Karamata, D. (1970). Multiple density classes of phage $\mathrm{Pl}$ due to tetramer formation. Molecular and General Genetics 107, 243-255.

KoSER, S. A. (1926). Action of bacteriophage on a thermophilic Bacillus. Proceedings of the Society for Experimental Biology and Medicine 24, 109-118.

MARMUR, J. \& DotY, P. (1962). Determination of the base composition of DNA from its thermal denaturation temperature. Journal of Molecular Biology $\mathbf{5}$, 109-118.

Munster, M. J., Sharp, R. J., Ahmad, A., Vivian, A. \& ATKINson, T. (1982). Transformation and transduction in a Bacillus thermophile. Abstracts of the XIIIth International Congress of Microbiology, Boston, USA, P28:12, p. 102.

ONODERA, N. (1961). On some characteristics of a newly isolated thermophilic bacteriophage and consideration of its thermostability. Journal of Electron Microscopy 10, 91-102.

PricketT, P.S. (1928). Thermophilic and thermoduric microorganisms with special reference to species isolated from milk. Description of spore forming types. New York State Agricultural Station Technical Bulletin no. 147.

RabusSaY, D., Zillig, W. \& Herrlich, P. (1970). Characterisation of the Bacillus stearothermophilus phage $\phi \mu-4$ and its DNA. Virology 41, 91-100.

REANNEY, D. C. \& Wood, M. (1973). Phages for facultatively thermophilic strains of Bacillus stearothermophilus: phage D-5. New Zealand Journal of Science 16, 681-695.

Romig, W. R. \& BRodetsky, A. M. (1961). Isolation and preliminary characterisation of bacteriophages of Bacillus subtilis. Journal of Bacteriology 82, 135141.

SargeanT, K., East, D. N., Whitaker, A. R. \& ELSWORTH, R. (1971). Production of Bacillus stearothermophilus NCA 1503 for glyceraldehyde-3-phosphate dehydrogenase. Journal of General Microbiology 65, iii. 
Saunders, G. G. \& Campbell, L. L. (1965). Properties of the deoxyribonucleic acid of the thermophilic bacteriophage TP-84. Biochemistry 4, 2836-2844.

Shafia, F. \& Thompson, T. L. (1964). Isolation and preliminary characterisation of bacteriophage $\phi \mu-4$. Journal of Bacteriology 87, 999-1002.

SHARP, R. J. (1982). Taxonomic and genetic studies of Bacillus thermophiles. PhD thesis, CNAA, London.

Sharp, R. J. \& WoOdRow, J. R. (1982). Numerical taxonomy of Bacillus thermophiles. Abstracts of the XIIIth International Congress of Microbiology, Boston, $U S A, \mathrm{P} 6: 1$, p. 62.

Sharp, R. J., Bown, K. J. \& Atkinson, A. (1980). Phenotypic and genotypic characterization of some thermophilic species of Bacillus. Journal of General Microbiology 117, 201-210.

ThOMPSON, T. L. \& Shafia, F. (1962). Energy requirement for adsorption of bacteriophage $\phi-4^{\prime}$. Biochemical and Biophysical Research Communications 8, 467-470.

WALKER, P. D. \& Wolf, J. (1971). The taxonomy of Bacillus stearothermophilus. In Spore Research, pp.
247-262. Edited by A. N. Barker, G. W. Gould \& J. Wolf. London: Academic Press.

Welker, N. E. \& CAMPBell, L. L. (1965). Induction and properties of a temperate bacteriophage from Bacillus stearothermophilus. Journal of Bacteriology 89, 175-184.

White, R., Georgi, C. E. \& Militzer, W. E. (1955). Characteristics of a thermophilic bacteriophage. Proceedings of the Society for Experimental Biology and Medicine 88, 373-377.

Wilson, G. A., Williams, M. T., Baney, H. W. \& YounG, F. E. (1974). Characterisation of temperate bacteriophages of $B$. subtilis by the restriction endonuclease EcoRI: evidence for three different temperate bacteriophages. Journal of Virology 14, 1013-1016.

WOLF, J. \& SHARP, R. J. (1981). Taxonomic and related aspects of thermophiles within the Genus Bacillus. In The Aerobic Endospore-forming Bacteria: Classifcation and Identification, pp. 251-296. Edited by R. C. W. Berkeley \& M. Goodfellow. London: Academic Press. 